\title{
THE EFFECT OF WOOD TYPE, TIME AFTER EXPOSURE AND CONCENTRATION ON TERMIT RESPONSE Microcerotermes diversus Silv. FOR SOME ANTIBIOTICS
}

\author{
Emad Q. Alebady ${ }^{1} \quad$ Hamad M. Hamad ${ }^{2}$ \\ ${ }^{1,2}$ University of Mosul / College of Agriculture and Forestry / Department of Plant \\ Protection \\ Email: dr.emad_alebady@uomosul.edu.iq
}

\begin{abstract}
The results of the study showed the effect of Leucaena leucocephala, Platanus orientalis and Populus alba woods, Concentrations were 0.0025, 0.005, and $0.01 \%$ in the Microcerotermes diversus Silv. workers response for Antibiotic Amoxicillin and Nidazole, by spraying and dipping methods, in medium-contrast ratios of insect mortality on the three kind of wood, as it reached: $63.10 \%, 48.75 \%$ and $50.10 \%$ respectively by spray, which gave an average rate of mortality after six days $99.38 \%$. While the results showed an increase in the average mortality rates of Termites with an increase in concentration $(0.0025,0.005$ and $0.01 \%)$, reaching 42.73 , 54.60 and $64.70 \%$, respectively, while Nidazole had a clear superiority in the average percentage of deaths of Microcerotermes diversus Silv. , as it reached $61.17 \%$, while it reached $46.86 \%$ for amoxicillin. As for the results of the dipping method, there was no significant difference in wood type in the average mortality rates, as it reached 53.62, 56.86 and $51.49 \%$, respectively, while the highest average mortality rate after four days of exposure was $88.23 \%$. Concentrations reached $41.50,54.73$ and $65.75 \%$, respectively, Amoxicillin and Nidazole did not have a significant difference in the mean Termites mortality as it reached 53.92 and $54.06 \%$.
\end{abstract}

Key Words: Amoxicillin, Nidazole, Termites, Wood .

Received : 18 /4/2002 , Accepted: 2 /6 /2020

\section{INTRODUCTION}

Termites belong to Isopteran and are one of the real social insects that live in the form of large colonies whose number ranges from a few hundred to several million and each group of them is specialized in performing a specific work, and some species resort to building their colonies under the surface of the soil and at various depths that may be difficult to reach sometimes. One of its most important advantages is the existence of a castes system within a single colony (Pearce 1997$)$. Also, there are more than 2,600 species of Termites in the world, but it is only 70-80 types which are economically important (Abe et al., 2000). In Iraq, the type Microcerotermes diversus Silv. is one of the most important species economically, as it spreads to most

*Part of M.Sc. Thesis submitted by the second author 
provinces. The ground attacks all the resources that cellulose is entering into its formation, as it causes huge losses to agricultural crops, fruit trees, and forest trees, as well as housing, especially from them, and damages wooden parts in modern homes such as doors and wooden furniture (Mustafa, 2004). Due to the huge economic losses caused by the ground, the process of combating this insect has taken great care. The researchers have focused their efforts on finding the best means to combating this insect. Using effective pesticides to protect crops, trees and all manufactured wood, the most important of which are pesticides belonging to the oregano chlorine group and organophosphate. And other effective pesticides against this insect (Dawood and Mallah, 1993). A study by (Al-Mallah et al., 2009) showed that regent pesticides Thermidor and Dorspan were 2\% for 15 months and 100\% in the first month. As a result of the problems of pesticides and their side effects on the environment, the researchers resorted to finding safer and more effective ways to fight the Termites. Researchers have influenced the efforts of innovating new methods with what is known as the Electro- Gun. To combat insects such as the use of the throat tree (Creffield et al. ,1997), which is a medicinal plant known for its effectiveness against Termites (Nisar et al. , 2012). An alternative means of pesticides is the use of biological control with the fungus Isaria fumosorosea (Nasri, 2017). Given the dependence of the Termites on its nutrition for cellulose analysis on coexisting microorganisms in the posterior digestive tract represented by protozoa and bacteria producing cellulose enzyme (Breznak, 1982), the idea of research came from using antibiotics to eliminate these microorganisms and thus prevent cellulose decomposition and stop feeding it and thus protect the wood from this lesion.

\section{MATERIAL\& METHODS}

First: The source of the insect: The Termites insect was obtained from the affected trees (Luscinia, Melia azedarach Land Ailanthus Glandulosa) in the nursery of the Forestry of the Faculty of Agriculture and Forestry, and efected trees in the forests of Mosul. kept them in dark pots measured $(45 \times 30 \times 18 \mathrm{~cm})$ contains sawdust of the trees selected for study: Leucaena leucocephala, Platanus orientalis and Populus alba. The pots were transferred to the laboratory under temperature of $26 \pm 2^{\circ} \mathrm{C}$. and relative humidity $30 \pm 3 \%$, also was kept on moistening the sawdust for 10 days (period of study ).

Second: A study of the effect of wood type and some antibiotics on the mortality workers in the ground: The study was conducted in the laboratory of the Plant Protection Department / College of Agriculture and Forestry / University of Mosul using two types of antibiotics Metronidazole 200mg and Amoxicillin 250mg in three concentrations prepared after conducting several preliminary tests to test its toxin on Termites, and then determined the concentrations $(0.0025,0.005$, and 0.01$)$ and by two methods of treatment:

1- Spraying method: Each type of wood and (antibiotic) treatments consist of three replicates. each replicate put in Patri dish containing a filter paper and sawdust treated 
with a 1- litre manual sprinkler with two presses pressure $(1 \mathrm{ml})$ for each repeater of anti-pesticide concentrations. and comparison treatment was treated with distilled water only, the dishes were left after the treatment for a period of (15) minutes, after that, each dish added ten homogeneous workers The dishes were covered and left in a dark place in the laboratory at an average temperature of $26 \pm 2^{\circ} \mathrm{C}$ and relative humidity $30 \pm 3 \%$. mortality rate was calculated after 24 hours and continued reading until the death rates reached $100 \%$. The Abbot equation (1925) was used to correct the killing rates.

2- Dipping method: By dipping of sawdust in the antibiotic concentrations ( mention above) for 2 minutes, then the dishes were left after treatment for a period of 30 minutes and added ten homogeneous Termites, the control treatment was treated with distilled water only and left in a dark place in the laboratory at temperature of $26 \pm 2^{\circ}$ $\mathrm{C}$ and humidity relative $30 \pm 3 \%$ The mortality percentage was calculated after 24 hours, and readings continued to be taken until killing ratios were reached to $100 \%$ used the Abbot equation (1925) to correct the mortality ratio.

LC 50 value, confidence and inclination limits were calculated according to Finney Method, and toxicity and efficacy index were calculated relativity of antibodies according to the following equations : (Al-Mallah and Abdel-Razzaq, 2012).

$$
\begin{aligned}
& \text { Toxicity index }=\quad \frac{L C 50 \text { value of the most ef ficient antigen tested }}{\delta L C 50 \text { value for the other antagonistx }} \times 100 \\
& \text { Relative efficiency }=\quad=\frac{L C 50 \text { value for least tested antibody }}{L C 50 \text { value for the other antagonist }} \times 100
\end{aligned}
$$

The results were analyzed using the complete global randomized design C.R.D using the Dunkin test to determine the difference between the averages based on the SAS package (1987).

\section{RESULTSAND DISCUSSION}

The results of Table (1) show the species effect of Leucaena leucocephala host, Platanus orientalis and Populus alba, and the time after exposure, in Termites's response to some Amoxicillin and Nidazole antibiotics by spraying. Variation in the average mortality rate of Termites in the three host used in the study, as it reached $63.10,48.75$ and $50.19 \%$, respectively. and the statistical analysis, showed siginatific difference between the average rate of killing Termites on $L$. leucocephala and the other host, $P$. orientalis and $P$. alba. These results explain that there are some woods that are resistant to the Termites due to reasons that may not be well known. Others are sensitive to the insect, as a result of the difference in the basic chemical components of wood (Mustafa, 2004), and the same table show that the average rate of killing Termites is directly proportional to the increase in time after exposure from 1 day to 6 days. The results of the statistical analysis showed that there is a clear significant 
Table (1):The effect of wood type and time after exposure on $M$. diversus silv workers response for some antibiotics (spray method)

\begin{tabular}{|c|c|c|c|c|c|c|c|c|c|c|c|c|}
\hline \multirow{3}{*}{$\begin{array}{l}\text { Wood } \\
\text { type }\end{array}$} & \multirow{3}{*}{$\begin{array}{c}\text { Antibiotic } \\
\text { type }\end{array}$} & \multirow[t]{3}{*}{ Conc. } & \multicolumn{6}{|c|}{$\%$ Mean of mortality } & \multirow{3}{*}{$\begin{array}{l}\text { influence } \\
\text { effect between } \\
\text { wood type, } \\
\text { antibiotic } \\
\text { and conc. }\end{array}$} & \multirow{3}{*}{$\begin{array}{c}\text { General } \\
\text { average } \\
\text { of } \\
\text { antibiot } \\
\text { ics }\end{array}$} & \multirow{3}{*}{$\begin{array}{l}\text { General } \\
\text { average } \\
\text { of the } \\
\text { con. }\end{array}$} & \multirow{3}{*}{$\begin{array}{l}\text { Gener } \\
\text { al } \\
\text { avera } \\
\text { ge } \\
\text { wood } \\
\text { type }\end{array}$} \\
\hline & & & \multicolumn{6}{|c|}{ Time after exposure / hours } & & & & \\
\hline & & & 24 & 48 & 72 & 96 & 120 & 144 & & & & \\
\hline \multirow{6}{*}{ Lucinia } & \multirow[t]{3}{*}{ Amoxicillin } & 0.0025 & $3.70 \mathrm{st}^{*}$ & $3.70 \mathrm{st}$ & $7.37 \mathrm{rst}$ & $51.68 \mathrm{c}-\mathrm{q}$ & $73.97 \mathrm{a}-\mathrm{h}$ & $100 \mathrm{a}$ & $40.10 \mathrm{gf}$ & & & \multirow{6}{*}{$\begin{array}{c}63.10 \\
\mathrm{a}\end{array}$} \\
\hline & & 0.005 & $22.191-\mathrm{t}$ & $36.85 \mathrm{~g}-\mathrm{t}$ & $44.30 \mathrm{e}-\mathrm{s}$ & $59.15 \mathrm{a}-\mathrm{m}$ & $81.41 \mathrm{a}-\mathrm{f}$ & $100 \mathrm{a}$ & 57.32 cde & & & \\
\hline & & 0.01 & $25.74 \mathrm{k}-\mathrm{t}$ & $59.08 \mathrm{a}-\mathrm{m}$ & $77.67 \mathrm{a}-\mathrm{g}$ & 85.10 a-e & 88.83 a-d & $100 \mathrm{a}$ & $72.74 \mathrm{ab}$ & & & \\
\hline & \multirow[t]{3}{*}{ Nidazole } & 0.0025 & $3.70 \mathrm{st}$ & $40.57 \mathrm{f}-\mathrm{t}$ & $48.01 \mathrm{~d}-\mathrm{r}$ & $62.86 \mathrm{a}-1$ & 85.14 a-e & $100 \mathrm{a}$ & 56.72 cde & & & \\
\hline & & 0.005 & $7.24 \mathrm{rst}$ & $40.57 \mathrm{f}-\mathrm{t}$ & $77.78 \mathrm{a}-\mathrm{g}$ & $88.89 \mathrm{a}-\mathrm{d}$ & $96.29 \mathrm{a}-\mathrm{b}$ & $100 \mathrm{a}$ & $68.47 \mathrm{bc}$ & & & \\
\hline & & 0.01 & $29.43 \mathrm{i}-\mathrm{t}$ & $77.70 \mathrm{a}-\mathrm{g}$ & $92.59 \mathrm{abc}$ & $100 \mathrm{a}$ & $100 \mathrm{a}$ & $100 \mathrm{a}$ & $83.29 \mathrm{a}$ & & & \\
\hline \multirow{6}{*}{ Platanus } & \multirow[t]{3}{*}{ Amoxicillin } & 0.0025 & $3.54 \mathrm{st}$ & $7.26 \mathrm{rst}$ & $10.99 \mathrm{q}-\mathrm{t}$ & $25.61 \mathrm{k}-\mathrm{t}$ & $57.13 \mathrm{~b}-\mathrm{n}$ & $100 \mathrm{a}$ & $34.09 \mathrm{~g}$ & & & \multirow{6}{*}{$\begin{array}{c}48.75 \\
b\end{array}$} \\
\hline & & 0.005 & $3.54 \mathrm{st}$ & $7.26 \mathrm{rst}$ & $14.42 \mathrm{o}-\mathrm{t}$ & $40.87 \mathrm{f}-\mathrm{t}$ & 79.98 a-f & $100 \mathrm{a}$ & $41.01 \mathrm{fg}$ & & & \\
\hline & & 0.01 & $3.54 \mathrm{st}$ & $14.71 \mathrm{o}-\mathrm{t}$ & $21.871-\mathrm{t}$ & $48.34 \mathrm{~d}-\mathrm{r}$ & $91.63 \mathrm{abc}$ & $100 \mathrm{a}$ & $46.68 \mathrm{dg}$ & & & \\
\hline & \multirow[t]{3}{*}{ Nidazole } & 0.0025 & $10.99 \mathrm{q}-\mathrm{t}$ & $14.42 \mathrm{o}-\mathrm{t}$ & $25.94 \mathrm{k}-\mathrm{t}$ & 38.03 g-t & $76.25 \mathrm{a}-\mathrm{g}$ & $100 \mathrm{a}$ & $44.27 \mathrm{dg}$ & & & \\
\hline & & 0.005 & $18.14 \mathrm{~m}-\mathrm{t}$ & $25.61 \mathrm{k}-\mathrm{t}$ & $33.39 \mathrm{~h}-\mathrm{t}$ & $80.00 \mathrm{a}-\mathrm{f}$ & $95.82 \mathrm{a}-\mathrm{b}$ & $100 \mathrm{a}$ & $58.83 \mathrm{bcd}$ & & & \\
\hline & & 0.01 & $29.36 \mathrm{i}-\mathrm{t}$ & $40.41 \mathrm{f}-\mathrm{t}$ & $59.53 \mathrm{a}-\mathrm{m}$ & $80.44 \mathrm{a}-\mathrm{f}$ & $95.82 \mathrm{a}-\mathrm{b}$ & $100 \mathrm{a}$ & $67.62 \mathrm{bc}$ & & & \\
\hline \multirow{6}{*}{$\begin{array}{l}\text { Populus } \\
\text { alba }\end{array}$} & \multirow[t]{3}{*}{ Amoxicillin } & 0.0025 & $0.00 \mathrm{t}$ & $0.00 \mathrm{t}$ & $8.19 \mathrm{rst}$ & $32.50 \mathrm{~h}-\mathrm{t}$ & 70.06 a- i & $88.8 \mathrm{ad}$ & $33.26 \mathrm{~g}$ & & & \multirow{6}{*}{$\begin{array}{c}50.19 \\
b\end{array}$} \\
\hline & & 0.005 & $8.24 \mathrm{rst}$ & $12.37 \mathrm{p}-\mathrm{t}$ & $28.32 \mathrm{j}-\mathrm{t}$ & $40.41 \mathrm{~g}-\mathrm{t}$ & $68.34 \mathrm{a}-\mathrm{j}$ & $100 \mathrm{a}$ & $42.94 \mathrm{efg}$ & & & \\
\hline & & 0.01 & $16.54 \mathrm{n}-\mathrm{t}$ & $24.15 \mathrm{k}-\mathrm{t}$ & $40.40 \mathrm{f}-\mathrm{t}$ & $55.78 \mathrm{~b}-\mathrm{o}$ & 84.60 a-e & $100 \mathrm{a}$ & $53.58 \mathrm{cf}$ & & & \\
\hline & \multirow[t]{3}{*}{ Nidazole } & 0.0025 & $4.13 \mathrm{st}$ & $28.33 \mathrm{j}-\mathrm{t}$ & $40.84 \mathrm{f}-\mathrm{t}$ & $44.58 \mathrm{e}-\mathrm{s}$ & 70.06 a- i & $100 \mathrm{a}$ & $47.99 \mathrm{dg}$ & & & \\
\hline & & 0.005 & $8.30 \mathrm{rst}$ & $40.86 \mathrm{f}-\mathrm{t}$ & $53.40 \mathrm{c}-\mathrm{p}$ & $70.51 \mathrm{a}-\mathrm{i}$ & $81.31 \mathrm{a}-\mathrm{f}$ & $100 \mathrm{a}$ & $59.06 \mathrm{bcd}$ & & & \\
\hline & & 0.01 & $12.36 \mathrm{p}-\mathrm{t}$ & $45.04 \mathrm{e}-\mathrm{s}$ & $65.92 \mathrm{a}-\mathrm{k}$ & $77.58 \mathrm{a}-\mathrm{g}$ & 85.05 a-e & $100 \mathrm{a}$ & $64.32 \mathrm{bc}$ & & & \\
\hline \multirow{2}{*}{\multicolumn{2}{|c|}{$\begin{array}{c}\text { Interaction between } \\
\text { antibiotic type \& time } \\
\text { after exposure }\end{array}$}} & Amoxicillin & $9.67 \mathrm{~g}$ & $18.38 \mathrm{fg}$ & $28.19 \mathrm{f}$ & $48.83 \mathrm{de}$ & $77.33 \mathrm{c}-\mathrm{b}$ & $98.75 \mathrm{a}$ & & $46.85 \mathrm{~b}$ & & \\
\hline & & Nidazole & $13.74 \mathrm{~g}$ & $39.30 \mathrm{e}$ & $55.27 \mathrm{~d}$ & $71.43 \mathrm{c}$ & $87.30 \mathrm{~b}$ & $100 \mathrm{a}$ & & $61.17 \mathrm{a}$ & & \\
\hline \multirow{3}{*}{\multicolumn{2}{|c|}{$\begin{array}{l}\text { Interaction between } \\
\text { focus \& time } \\
\text { after exposure }\end{array}$}} & 0.0025 & $4.343 \mathrm{i}$ & 15.71 ghi & $23.56 \mathrm{gh}$ & $42.54 \mathrm{f}$ & 72.10 cde & $98.13 \mathrm{a}$ & & & $42.73 \mathrm{c}$ & \\
\hline & & 0.005 & $11.26 \mathrm{i}$ & $27.25 \mathrm{~g}$ & $41.93 \mathrm{f}$ & $63.30 \mathrm{de}$ & $83.85 \mathrm{bc}$ & $100 \mathrm{a}$ & & & $54.60 \mathrm{~b}$ & \\
\hline & & 0.01 & $19.49 \mathrm{gh}$ & $43.54 \mathrm{f}$ & $59.67 \mathrm{e}$ & $74.53 \mathrm{~cd}$ & $90.99 \mathrm{ab}$ & $100 \mathrm{a}$ & & & $64.70 \mathrm{a}$ & \\
\hline \multicolumn{3}{|c|}{ General average time after exposure } & $11.70 \mathrm{f}$ & $28.84 \mathrm{e}$ & $41.72 \mathrm{~d}$ & $60.13 \mathrm{c}$ & $82.32 \mathrm{~b}$ & $99.38 \mathrm{a}$ & & & & \\
\hline
\end{tabular}

Means with different letters in the same sectors showed a significant different at $\mathrm{p}=5 \%$ 
difference between the mean of the cumulative killing rate after exposure to antibiotics. The results of Table (1) proved that the type of antibiotics had a cleareffect on the average rate of mortality the workers of the soil, as Nidazole had a greater effect on the average rate of mortality Termites reached $61.17 \%$, while amoxicillin had a lower effect on the average rates of killing Termites also. Table (1) showed that the Concentration of antagonists $0.0025,0.005$, and 0.01 had a clear effect on increasing the mean of mortality percentage by increasing concentrations, as it reached $42.73,54.60$ and $64.70 \%$, respectively. The statistical analysis shows that there is a clear significant difference between the averages killing ratios between the three concentrations used in the study. From the triple interaction between the type of wood host, the anti and the concentration, it was found from the same table that the average mortality ratios of Termites showed a significant superiority over the $L$. leucocephala host and the anti-nidazole at a concentration of $0.01 .83 .29 \%$. Whereas, the lowest mean killing rate for the P. alba host and anti-amoxicillin at $0.0025 \%$, as it reached $33.26 \%$. and that there was a little difference in the mean of killing ratios on the $L$. leucocephala host and the anti-nidazole at a concentration of 0.01 , and the rest of the studied treatments. The results can be explained by the fact that amoxicillin has a lower effect than nidazole in the average rates of killing Termites because amoxicillin is highly effective on the aerobic bacteria that are positive for Gram dye while it has less effect on bacteria negative Gram, but nidazole has a broad-spectrum effect on the positive and negative bacteria of Gram stain (Kaur et al., 2011).

These results are in agreement with the values of LC 50 of the used antagonists, as shown in Table (2) that the lowest value of the $\mathrm{LC}_{50}$ of the anti-nidazole on $L$. leucocephala wood was 0.002 , The highest value of $\mathrm{LC}_{50}$ amounted to the antioxidant amoxicillin 0.013 on the wood of Platanus orientalis, which indicates a low toxicity of amoxicillin on Termites. The effect of the broad spectrum nidazole antibiotic may be attributed to the inhibition of $\mathrm{G}$ positive and negative bacteria in the Gram stain and in the inhibition of protozoa in stopping the synthesis of the DNA and RNA nucleic acids of bacteria and protozoa (Soares et al. , 2012)

In the same table, the toxicity index of the antidote to nidazole on Lucinia wood reached 100, while the relative toxicity value was 650 . From statistical analysis, we note a clear significant difference at the probability level of 5\% of the toxicity index values and relative toxicity according to the antibiotic and wood type.

Table (3) showed the effect of the species of L. leucocephala, P. orientalis and $P$. alba and the time after exposure in the response of Termites to some amoxicillin and nidazole antibiotics by dipping method. Which reached 53.62, 56.86 and 51.49\%, respectively, and Statically has no significant moral difference between the average killing percentage of Termites over the three type host used in the study. And the results of the same table showed that the average rate of killing of Termites is directly proportional to the increase in time after exposure from 1 day to 4 days. The results of the statistical analysis showed that there is a clear significant difference between the 
Table (2): Values of half-lethal concentrations, inclination, confidence limits, toxicity index, and relative efficacy of some antibiotics in soil workers (spray method).

\begin{tabular}{|c|c|c|c|c|c|c|}
\hline \multirow{2}{*}{ Wood type } & $\begin{array}{c}\text { Antibiotic } \\
\text { type }\end{array}$ & The slope & LC $_{50}$ & $\begin{array}{c}\text { Confidence } \\
\text { limits }\end{array}$ & Toxicity Index & $\begin{array}{c}\text { Relative } \\
\text { Toxicity }\end{array}$ \\
\hline \multirow{2}{*}{ Lucinia } & Amoxicillin & 1.44 & 0.004 & $0.003-0.005$ & $50 \mathrm{c}^{*}$ & $325 \mathrm{c}$ \\
\cline { 2 - 7 } & Metranidazol & 1.28 & 0.002 & $0.001-0.003$ & $100 \mathrm{a}$ & $650 \mathrm{a}$ \\
\hline \multirow{2}{*}{ Platanus orientalis } & Amoxicillin & 0.56 & 0.013 & $0.01-0.022$ & $15.4 \mathrm{e}$ & $100 \mathrm{e}$ \\
\cline { 2 - 7 } & Metranidazol & 1.03 & 0.003 & $0.002-0.005$ & $66.67 \mathrm{~b}$ & $433.3 \mathrm{~b}$ \\
\hline \multirow{2}{*}{ Populus alba } & Amoxicillin & 0.90 & 0.008 & $0.005-0.02$ & $25 \mathrm{~d}$ & $162.5 \mathrm{~d}$ \\
\cline { 2 - 7 } & Metranidazol & 0.68 & 0.003 & $0.001-0.004$ & $66.67 \mathrm{~b}$ & $433.3 \mathrm{~b}$ \\
\hline
\end{tabular}

Means with different letters in the same sectors showed a significant different at $\mathrm{p}=5 \%$ 
Table (3): Effect of wood type and time after exposure on response of M. diversussilv workers for some antibiotics (by dipping).

\begin{tabular}{|c|c|c|c|c|c|c|c|c|c|c|}
\hline \multirow[t]{2}{*}{ Wood type } & \multirow{2}{*}{$\begin{array}{l}\text { Antibiotic } \\
\text { type }\end{array}$} & \multirow[t]{2}{*}{ Conc. } & \multicolumn{4}{|c|}{$\%$ Murder rate } & \multirow{2}{*}{$\begin{array}{l}\text { influence } \\
\text { effect } \\
\text { between } \\
\text { wood type, } \\
\text { antibiotic } \\
\text { and conc. }\end{array}$} & \multirow{2}{*}{$\begin{array}{c}\text { General } \\
\text { average } \\
\text { of } \\
\text { antibiotic } \\
\mathrm{s}\end{array}$} & \multirow{2}{*}{$\begin{array}{l}\text { General } \\
\text { average } \\
\text { of the } \\
\text { con. }\end{array}$} & \multirow{2}{*}{$\begin{array}{c}\text { General } \\
\text { average } \\
\text { wood } \\
\text { type }\end{array}$} \\
\hline & & & \multicolumn{4}{|c|}{ Time after exposure / hours } & & & & \\
\hline \multirow{6}{*}{ Lucinia } & \multirow[t]{3}{*}{ Amoxicillin } & 0.0025 & $9.82 \mathrm{n}-\mathrm{q}$ & $20.59 \mathrm{i}-\mathrm{q}$ & $52.74 \mathrm{a}-\mathrm{p}$ & 85.10 abc & $42.06 \mathrm{~cd}$ & & & \multirow[t]{6}{*}{$53.62 \mathrm{a}$} \\
\hline & & 0.005 & $17.23 \mathrm{k-q}$ & $38.59 \mathrm{c}-\mathrm{q}$ & $78.02 \mathrm{a}-\mathrm{f}$ & $88.83 \mathrm{ab}$ & $55.67 \mathrm{ad}$ & & & \\
\hline & & 0.01 & $13.531-q$ & $63.50 \mathrm{a}-\mathrm{k}$ & $81.38 \mathrm{a}-\mathrm{e}$ & $100 \mathrm{a}$ & $64.60 \mathrm{abc}$ & & & \\
\hline & \multirow[t]{3}{*}{ Nidazole } & 0.0025 & $6.81 \mathrm{opq}$ & $27.99 \mathrm{~g}-\mathrm{q}$ & $53.10 \mathrm{a}-\mathrm{o}$ & 85.10 abc & $43.25 \mathrm{bcd}$ & & & \\
\hline & & 0.005 & $13.87 \mathrm{l}-\mathrm{q}$ & $38.59 \mathrm{c}-\mathrm{q}$ & $60.55 \mathrm{a}-\mathrm{m}$ & $88.83 \mathrm{ab}$ & $50.46 \mathrm{ad}$ & & & \\
\hline & & 0.01 & $24.12 \mathrm{~h}-\mathrm{q}$ & $60.14 \mathrm{a}-\mathrm{m}$ & $78.38 \mathrm{a}-\mathrm{f}$ & $100 \mathrm{a}$ & $65.66 \mathrm{ab}$ & & & \\
\hline \multirow{6}{*}{ Platanus orientalis } & \multirow[t]{3}{*}{ Amoxicillin } & 0.0025 & $9.82 n-q$ & $34.91 \mathrm{~d}-\mathrm{q}$ & $65.84 \mathrm{a}-\mathrm{k}$ & $83.33 \mathrm{a}-\mathrm{d}$ & $48.48 \mathrm{ad}$ & & & \multirow[t]{6}{*}{$56.86 \mathrm{a}$} \\
\hline & & 0.005 & $13.18 \mathrm{~m}-\mathrm{q}$ & $58.74 \mathrm{a}-\mathrm{m}$ & $72.13 \mathrm{a}-\mathrm{h}$ & $86.67 \mathrm{abc}$ & $57.68 \mathrm{abc}$ & & & \\
\hline & & 0.01 & $19.87 \mathrm{j}-\mathrm{q}$ & 48.72 b-p & $79.20 \mathrm{a}-\mathrm{f}$ & $100 \mathrm{a}$ & $61.95 \mathrm{abc}$ & & & \\
\hline & \multirow[t]{3}{*}{ Nidazole } & 0.0025 & $6.46 \mathrm{opq}$ & $34.50 \mathrm{e}-\mathrm{q}$ & $62.05 \mathrm{a}-1$ & 86.64 abc & $47.41 \mathrm{ad}$ & & & \\
\hline & & 0.005 & $13.16 \mathrm{~m}-\mathrm{q}$ & $47.91 \mathrm{~b}-\mathrm{q}$ & $75.84 \mathrm{a}-\mathrm{g}$ & $96.67 \mathrm{ab}$ & $58.39 \mathrm{abc}$ & & & \\
\hline & & 0.01 & $23.68 \mathrm{i}-\mathrm{q}$ & $58.74 \mathrm{a}-\mathrm{m}$ & $86.67 \mathrm{abc}$ & $100 \mathrm{a}$ & $67.27 \mathrm{a}$ & & & \\
\hline \multirow{6}{*}{ Populus alba } & \multirow[t]{3}{*}{ Amoxicillin } & 0.0025 & $4.07 \mathrm{pq}$ & $27.72 \mathrm{~g}-\mathrm{q}$ & $48.15 \mathrm{~b}-\mathrm{q}$ & 55.55 a-n & $33.87 \mathrm{~d}$ & & & \multirow[t]{6}{*}{$51.49 \mathrm{a}$} \\
\hline & & 0.005 & $4.07 \mathrm{pq}$ & $52.14 \mathrm{a}-\mathrm{p}$ & $72.11 \mathrm{a}-\mathrm{h}$ & $87.91 \mathrm{ab}$ & $54.06 \mathrm{ad}$ & & & \\
\hline & & 0.01 & $19.36 \mathrm{j}-\mathrm{q}$ & $60.51 \mathrm{a}-\mathrm{m}$ & $87.91 \mathrm{a}-\mathrm{b}$ & $100 \mathrm{a}$ & $66.95 \mathrm{a}$ & & & \\
\hline & \multirow[t]{3}{*}{ Nidazole } & 0.0025 & $00.0 \mathrm{q}$ & $31.90 \mathrm{f}-\mathrm{q}$ & $48.15 \mathrm{~b}-\mathrm{q}$ & 55.55 a-n & $33.90 \mathrm{~d}$ & & & \\
\hline & & 0.005 & $00.0 \mathrm{q}$ & $52.62 \mathrm{a}-\mathrm{p}$ & $67.92 \mathrm{a}-\mathrm{j}$ & $87.91 \mathrm{ab}$ & $52.11 \mathrm{ad}$ & & & \\
\hline & & 0.01 & $23.34 \mathrm{i}-\mathrm{q}$ & $68.41 \mathrm{a}-\mathrm{i}$ & 80.50 a-f & $100 \mathrm{a}$ & $68.06 \mathrm{a}$ & & & \\
\hline \multirow{2}{*}{\multicolumn{2}{|c|}{$\begin{array}{l}\text { Interaction between antibiotic } \\
\text { type \& time after exposure }\end{array}$}} & Amoxicillin & $12.33 \mathrm{~d}$ & $45.05 \mathrm{c}$ & $70.83 \mathrm{~b}$ & $87.49 \mathrm{a}$ & & $53.92 \mathrm{a}$ & & \\
\hline & & Nidazole & $12.38 \mathrm{~d}$ & $46.76 \mathrm{c}$ & $68.13 \mathrm{~b}$ & $88.97 \mathrm{a}$ & & $54.06 \mathrm{a}$ & & \\
\hline \multirow{3}{*}{\multicolumn{2}{|c|}{$\begin{array}{c}\text { Interaction between focus \& time } \\
\text { after exposure }\end{array}$}} & 0.0025 & $6.17 \mathrm{~h}$ & $29.60 \mathrm{~g}$ & 55.00 ef & $75.21 \mathrm{bcd}$ & & & $41.50 \mathrm{c}$ & \\
\hline & & 0.005 & $10.25 \mathrm{~h}$ & $48.10 \mathrm{f}$ & 71.10 cde & $89.47 \mathrm{ab}$ & & & $54.73 \mathrm{~b}$ & \\
\hline & & 0.01 & $20.65 \mathrm{gh}$ & $60.00 \mathrm{def}$ & $82.34 \mathrm{bc}$ & $100 \mathrm{a}$ & & & $65.75 \mathrm{a}$ & \\
\hline \multicolumn{3}{|c|}{ General average time after exposure } & $12.37 \mathrm{~d}$ & $45.90 \mathrm{c}$ & $69.48 \mathrm{~b}$ & $88.23 \mathrm{a}$ & & & & \\
\hline
\end{tabular}

Means with different letters in the same sectors showed a significant different at $\mathrm{p}=5 \%$ 
mean of the cumulative killing rate after exposure to antibiotics. The results of Table (3) showed the type of antibiotics did not have a clear effect on the average killing rate of Termites, as it reached $53.92 \%$ for Amoxicillin 54.06\% for nidazole, which gaveclose killing rates, while the results of Table (3) showed the average killing rates of Termites increased with increasing the concentration of antibiotics Vitality is $0.0025,0.005$, and 0.01 as it is $41.50,54.73$ and $65.75 \%$, respectively. And between the statistical analysis and the presence of a clear moral difference between the averages of the killing ratios between the three concentrations used in the study. From the three-way overlap between the type of food host and the anti and the concentration, it was found from the same table that the average ratios of killing the Termites showed a significant superiority over the host of $P$. alba and the anti-nidazole at a concentration of $0.01 \%$, the percentage was $68.06 \%$, while the lowest mean death rate for the host was white and anti-amoxicillin at $0.0025 \%$, when it reached $33.87 \%$. From the results of the statistical analysis, we note that there is only a significant difference in the mean killing rates on the anti-nidazole at a concentration of $0.001 \%$ and the rest of the studied factors in the search . These results are in agreement with the LC 50 values for the antigen used by immersion method, as shown in Table (4). The LC ${ }_{50}$ values for the antioxidant amoxicillin and nidazole on the three woods $L$. leucocephala, $P$. orientalis and P. alba were close between 0.003-0.005, and this indicates the toxicity of the antibodies to Termites were close due to the absorption of the wood by the antibodies. From the same table, we note that the toxicity index and the relative toxicity of antagonists were also close, as the highest toxicity index value reached 100 for antagonists. And nidazole on wood of the eastern paradise, while it

Table (4): Values of half-lethal concentrations, inclination, confidence limits, toxicity index, and relative efficacy of some antibiotics in soil workers (spraying method).

\begin{tabular}{|c|c|c|c|c|c|c|}
\hline Wood type & $\begin{array}{c}\text { Antibiotic } \\
\text { type }\end{array}$ & $\begin{array}{c}\text { The } \\
\text { slope }\end{array}$ & $\mathrm{LC}_{50}$ & $\begin{array}{c}\text { Confidence } \\
\text { limits }\end{array}$ & $\begin{array}{c}\text { Toxicity } \\
\text { Index }\end{array}$ & $\begin{array}{c}\text { Relative } \\
\text { toxicity }\end{array}$ \\
\hline \multirow{2}{*}{ Lucinia } & Amoxicillin & 0.97 & 0.004 & $0.002-0.005$ & $75 \mathrm{~b}$ & $125 \mathrm{~b}$ \\
\cline { 2 - 7 } & Metranidazol & 0.98 & 0.004 & $0.002-0.006$ & $75 \mathrm{~b}$ & $125 \mathrm{~b}$ \\
\hline \multirow{2}{*}{ Platanus orientalis } & Amoxicillin & 0.55 & 0.003 & $0.001-0.004$ & $100 \mathrm{a}$ & $166.7 \mathrm{a}$ \\
\cline { 2 - 7 } & Metranidazol & 0.86 & 0.003 & $0.001-0.004$ & $100 \mathrm{a}$ & $166.7 \mathrm{a}$ \\
\hline \multirow{2}{*}{ Populus alba } & Amoxicillin & 1.42 & 0.005 & $0.004-0.006$ & $60 \mathrm{c}$ & $100 \mathrm{c}$ \\
\cline { 2 - 7 } & Metranidazol & 1.46 & 0.005 & $0.004-0.006$ & $60 \mathrm{c}$ & $100 \mathrm{c}$ \\
\hline
\end{tabular}

"Means with different letters in the same sectors showed a significant different at $\mathrm{p}=5 \%$ 
was the least toxic evidence of the antagonists on white wormwood, it reached 60 , while the highest relative toxicity of antioxidants on the wood of eastern paradise was 166.7 and the lowest toxicity of anti-white pomegranate was 100 (Table 4).

\section{تأثير نوع الخثب والوقت بعد التعريض والتركيز في استجابة شغالات الارضة \\ Microcerotermes diversus Silv.

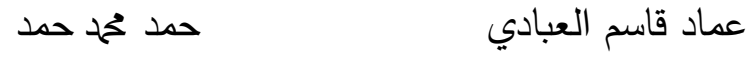 \\ جامعة الموصل / كلية الزراعة والغابات / قسم وقاية النبات \\ Email: dr.emad_alebady@uomosul.edu.iq}

\section{الخلاصة}

أظهرت نتائج الدراسة تأثير نوع الخشب اللوسينيا والجنار الثرقي والقوغ الابيض والتركيز 0.0025 و 0.005 و 0.01 \% في استجابة شغالات الارضة . للمضادين

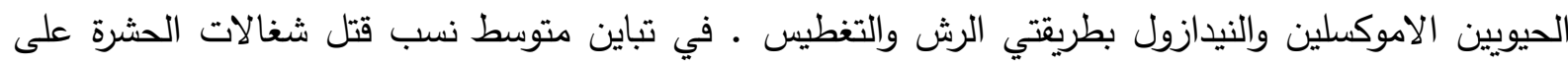
العوائل الثلاثة اذ بلغت 63.10 و 48.75 و 50.19 \% على التوالي بالرش ، وسجلت اعلى متوسط نسبة قتل بعد التعريض بستة ايام 99.38\% ، فيما اظهرت النتائج زيادة متوسطات نسب قتل شغالات الارضة بزيادة التركيز (0.025 و 0.005 و 0.01\%) اذ بلغت 42.73 و 54.60 و 64.70 \% على على التوالي فيما كان للنيدازول تفوق واضح في متوسط نسبة قتل شغالات الارضة اذ بلغ 61.17\% بينما بلغ

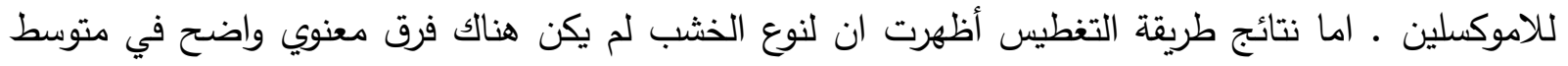

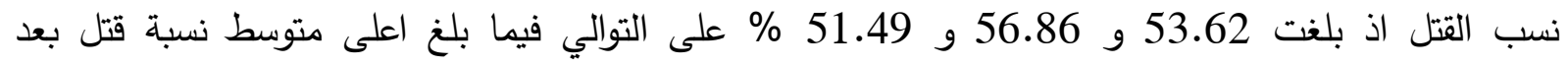

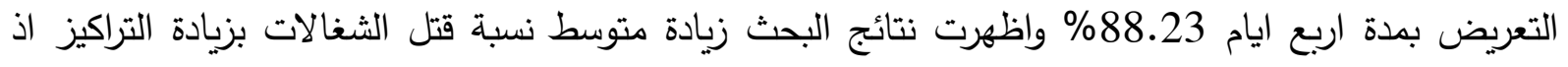

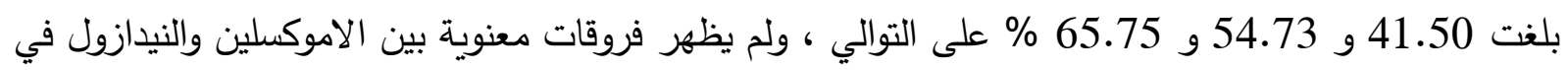

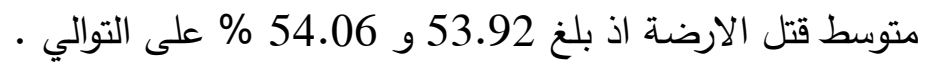
الكلمات الدالة : الاموكسلين ، النيدازول ، الأرضة ، الأخثاب.

تاريخ تسلم البحث: 2020 ، وقبوله: 6/2/18/ 2020

\section{REFERENCES}

Abbott, W. S. (1925). A method of computing the effectiveness of an insecticide. Journal Economic of Entomology. 18:(2)265-267.

Abe, T., Bignell, D. E., Higashi, M., Higashi, T., \& Abe, Y. (Eds.). (2000). Termites: Evolution, Sociality, Symbioses, Ecology. Springer Science \& Business Media. 
Al-Mallah, N. M. and Abdul-Razzaq Y. al-Juburi (2012). Chemical Pesticides, their groups, Methods of Influence and Metabolism in Organisms and the Environment. Alalla Publishing. Mosul. Iraq.350p.

Al-Mallah, N. M., Shaheen A. M., Walid A. K. (2009). Evaluating the efficacy of some insecticides in protecting parasitic wood from termite infection Microcerotermes diversus Silv. (Isoptra: Termitidae). Kirkuk University. Journal for Scientific Studies.4 (1)72-80.

Breznak, J. A. (1982). Intestinal micro biota of termites and other xylophages insects. Annual Reviews in Microbiology. 36(1), 323-323.

Creffield, J. W. ; French, J. R. J. and Chew, N. (1997). A laboratory assessinent of the effectiveness of the Electro-Gun in eradicating adults of Crytloterme sprimas ( Isoptera : Kalotermitidae ). CSIRO Forestry and Forest products Client Report N. 163, 6 pp.

Dawood, A. Sh. and Nizar Mustafa Al-Mallah (1993) Pesticides. Dar Al-Kutub for Printing and Publishing. Mosul University, 520 pages.

Kaur, S. P., Rao, R., \& Nanda, S. A. N. J. U. (2011). Amoxicillin: a broad spectrum antibiotic. International of Journal Pharmacia Science . 3(3)30-7.

Mustafa, S. A.(2004).A study of the reasons for nutritional preference for termites for some types of Iraqi wood and its chemical control Microcerotermes diversus Silv. (Isoptra: Termitidae), PhD. University of Mosul .College of Agriculture and Forestry. Iraq.166p.

Nasri, Buraq Abdul-Hassan (2017), Vital evaluation of the fungus, Isaria fumosorosea (Wize) In the behavior and death of termites of Microcerotermes diversus Silv. (Isoptra: Termitidae) laboratory and field.

Nisar, M. S.; Ahmed ,S.; Rashid, A. and Ahmed, M.M.(2012 ). Toxicity of Piper nigrum seed extracts and effect on tunnel formation in termites. Journal of Pakistan Entomology . 34(1): 55-58.

Pearce, M. J.(1997). Termites : Biology and Pest Management. CAB International USA .172 pp.

SAS. (1987). SAS / STAT Guide for Personal Computers. Version 6 ed. SAS Institute Inc. Cary , N.C.

Soares, G. M. S., Figueiredo, L. C., Faveri, M., Cortelli, S. C., Duarte, P. M., and Feres, M. (2012). Mechanisms of action of systemic antibiotics used in periodontal treatment and mechanisms of bacterial resistance to these drugs. Journal of applied oral science, 20(3), 295-309. 